ఠ Open Access Full Text Article

CORRIGENDUM

\title{
Overexpression of HOXB4 Promotes Protection of Bone Marrow Mesenchymal Stem Cells Against Lipopolysaccharide-Induced Acute Lung Injury Partially Through the Activation of Wnt/ $\beta$-Catenin Signaling [Corrigendum]
}

\author{
Lin $\mathrm{S}$, Chen $\mathrm{Q}$, Zhang $\mathrm{L}$, et al. $J$ Inflamm Res. \\ 2021;14:3637-3649.
}

The authors have advised Figure $2 \mathrm{C}$ on page 3641 is incorrect. Due to an error at the time of figure assembly
Control and $\mathrm{BMSC}^{\mathrm{WT}}+\mathrm{LPS}$ in the $0 \mathrm{~h}$ row in figure part $\mathrm{C}$ were duplicated. The correct Figure 2 is shown below.

The authors apologize for this error and advise it does not affect the results of the paper. 
A

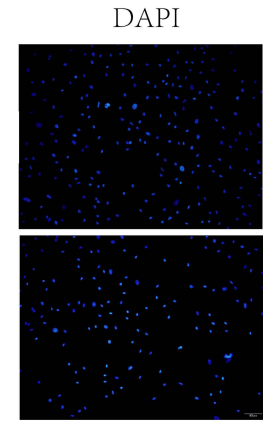

LPS

Control

BMSCWT+LPS $^{\text {WT }}$

BMSC Vector+LPS

$\mathrm{BMSC}^{\mathrm{HOXB} 4+\mathrm{LPS}}$

C

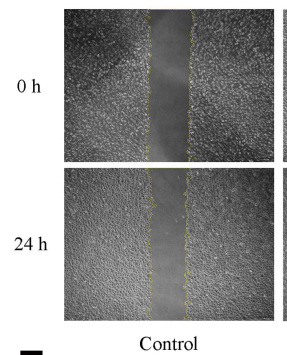

E

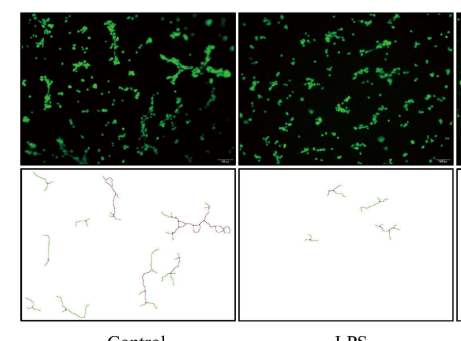

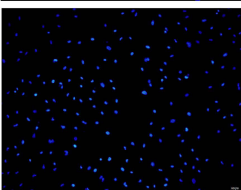
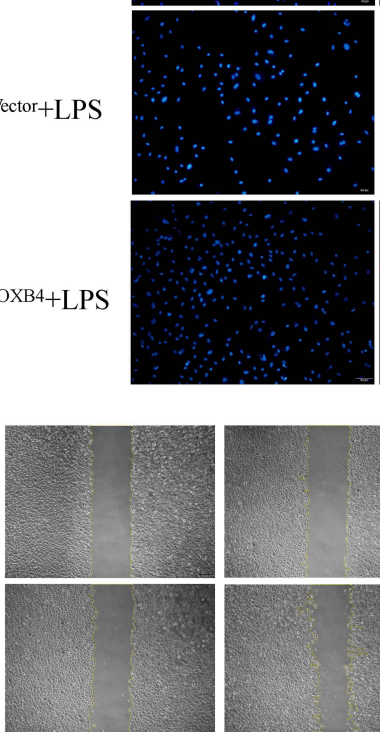

LPS

LPS

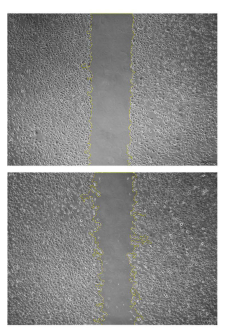

BMSC $^{\text {WT }}+$ LPS

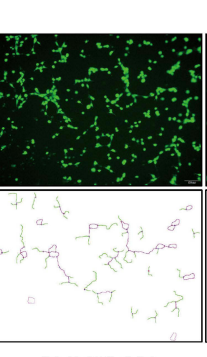

EdU
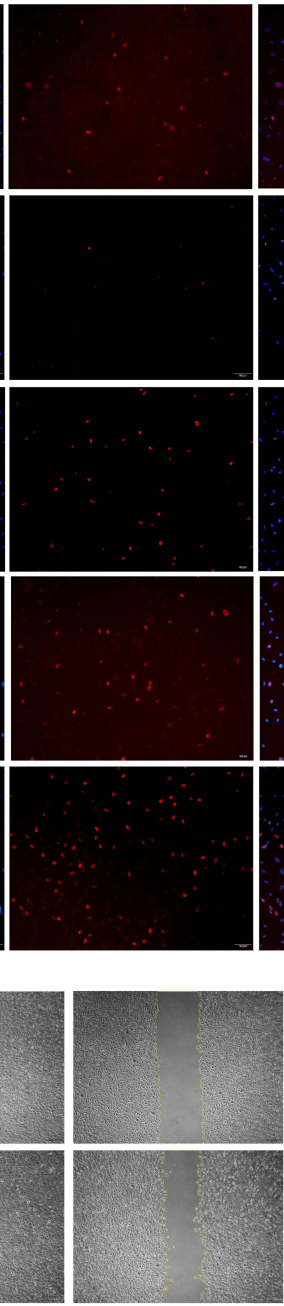

BMSC $C^{\text {Vector+LPS }}$

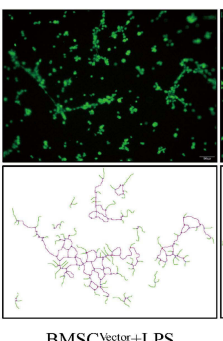

Merged
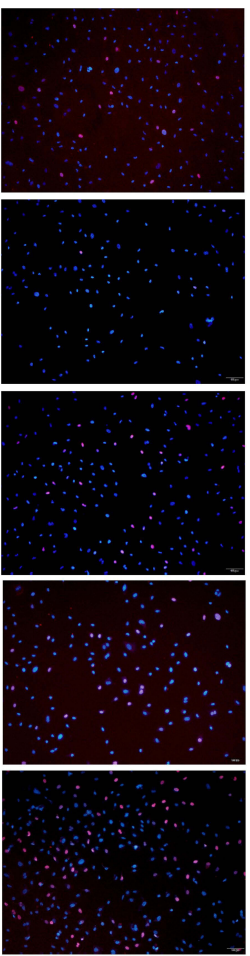

D

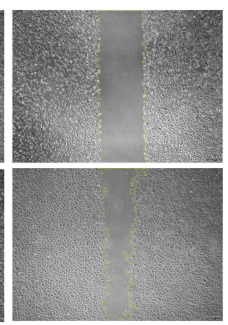

BMSC $^{\text {HохB4}}+\mathrm{LPS}$

F

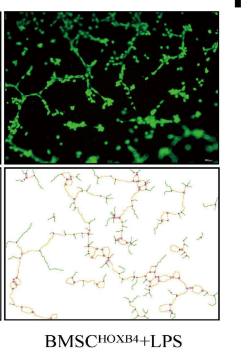

B
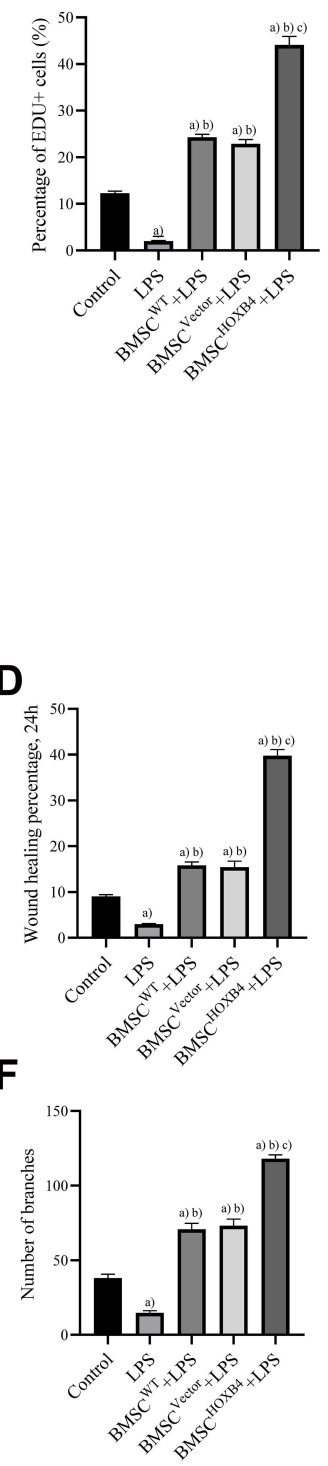

Figure 2 BMSC $^{\text {HOXB4 }}$ coculture promotes the proliferation, migration, and tube formation ability of ECs. (A) EdU was measured for EC proliferative capacity, of which the blue color indicated the nuclear localization and the red color indicated the proliferation-active cells (magnification I00x). (B) Quantitative analysis was conducted by calculating the percentage of proliferation-active cells, and the results suggested that BMSC ${ }^{\mathrm{HOXB} 4}$ coculture dramatically promoted EC proliferation capacity after LPSinduced injury compared to BMSC ${ }^{\mathrm{WT}}$ and $\mathrm{BMSC}^{\text {Vector }}$ coculture groups. (C) The scratch assay was conducted to assess the migration capability of EC, and representative images of the scratches at different time points at $0 \mathrm{~h}$ and $24 \mathrm{~h}$ are shown (magnification $40 \mathrm{x}$ ). (D) Quantitative analysis of the changes in the scratched areas was performed using Image J software, and results suggested that the migration ability of ECs was significantly increased in the BMSC ${ }^{\text {HOXB4 }}$ coculture group compared to BMSC $^{\text {WT }}$ and BMSC $^{\text {Vector }}$ coculture groups. (E) Tube formation assay was performed to detect EC angiogenic capacity, and Calcein AM fluorescent dye was used to enhance the visibility of tube and network formation in Matrigel (magnification 100x), along with the trajectories of tubes and networks were also depicted accordingly. (F) Quantitative analysis suggested that coculture with BMSC ${ }^{\mathrm{HOXB4}}$ significantly promoted the EC tube formation ability compared to that in BMSC ${ }^{\mathrm{WT}}$ and BMSC ${ }^{\mathrm{Vector}}$ coculture groups. Data were expressed as mean $\pm \mathrm{SD}(\mathrm{n}=3)$. ${ }^{\text {a) }}$ Compared to control group, $P<0.0 \mathrm{I}$; b) compared to LPS group, $P<0.01$; ${ }^{c}$ compared to BMSC ${ }^{W T}+\mathrm{LPS}$ group, $P<0.0 \mathrm{I}$.

Abbreviations: WT, wild-type; HOXB4, homeobox B4; BMSC, bone marrow mesenchymal stem cell; SD, standard deviation; EC, endothelial cell; EdU, 5-ethynyl-20deoxyuridine. 


\section{Publish your work in this journal}

The Journal of Inflammation Research is an international, peerreviewed open-access journal that welcomes laboratory and clinical findings on the molecular basis, cell biology and pharmacology of inflammation including original research, reviews, symposium reports, hypothesis formation and commentaries on: acute/chronic inflammation; mediators of inflammation; cellular processes; molecular mechanisms; pharmacology and novel anti-inflammatory drugs; clinical conditions involving inflammation. The manuscript management system is completely online and includes a very quick and fair peerreview system. Visit http://www.dovepress.com/testimonials.php to read real quotes from published authors.

Submit your manuscript here: https://www.dovepress.com/journal-of-inflammation-research-journal 